\title{
L-CARNITINE ADMINISTRATION EFFECTS ON AMPK, APPL1 AND PPAR $\gamma$ GENES EXPRESSION IN THE LIVER AND SERUM ADIPONECTIN LEVELS AND HOMA-IR IN TYPE 2 DIABETES RAT MODEL INDUCED BY STZ AND NICOTINAMIDE
}

\author{
B. SHAHOUZEHI ${ }^{1,2}$, H. FALLAH ${ }^{3}$, Y. MASOUMI-ARDAKANI ${ }^{\llbracket 凶}$ \\ ${ }^{1}$ Student Research Committee, Kerman University of Medical Sciences, Kerman, Iran; \\ ${ }^{2}$ Cardiovascular Research Center, Institute of Basic and Clinical Physiology \\ Sciences, Kerman University of Medical Sciences, Kerman, Iran; \\ ${ }^{3}$ Department of Biochemistry, Afzalipour School of Medicine, \\ Kerman University of Medical Sciences, Kerman, Iran; \\ ${ }^{4}$ Physiology Research Center, Institute of Basic and Clinical Physiology \\ Sciences, Kerman University of Medical Sciences, Kerman, Iran; \\ 凶e-mail: ymab125@gmail.com
}

Received: 18 January 2020; Accepted: 25 June 2020

Diabetes is a chronic disease and public health problem globally. L-Carnitine is synthesized in the liver, promotes fatty acids oxidation and currently is used as a supplement against weight gain. Carnitine level is found to be reduced in diabetic patients and to be beneficial as a supplement at diabetes, but the mechanisms of this effect is not fully understood. Therefore, we evaluated the oral L-carnitine supplementation on expression of AMP-activated protein kinase (AMPK), peroxisome proliferator-activated receptor gamma (PPAR ), adaptor protein APPL1 genes in the liver and insulin and adiponectin levels in the serum of diabetic rats. Rats were randomly divided into three groups $(n=8)$ as follow: group 1 - control without any treatment, group 2 - diabetic control rats which received $S T Z(45 \mathrm{mg} / \mathrm{kg})$ and nicotinamide $(200 \mathrm{mg} / \mathrm{kg})$ by i.p. injection, group 3 - diabetic rats which received $600 \mathrm{mg} / \mathrm{kg} /$ day carnitine orally for 35 days. It was found that L-carnitine supplementation reduced the level of fasting glucose compared to that in control and diabetic groups $(P=0.001, P=0.0001$ respectively) and increased adiponectin level compared to diabetic nontreated rats $(P=0.0001)$. Homeostasis model assessment of insulin resistance (HOMA-IR) was significantly increased in the diabetic group and reduced in the group that received L-carnitine. These promising beneficial effect of L-carnitine on the type 2 diabetes in rats' model was shown to be conducted through the up-regulation of AMPK, PPAR $\gamma$ and APPL1 genes expression in the liver and elevation of serum adiponectin level.

Keywords: L-carnitine, diabetes, nicotinamide, HOMA-IR, AMPK, PPAR\%, APPL1.

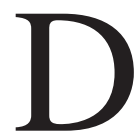
iabetes is a public health problem and its global prevalence was nearly 422 million adults [1]. Most diabetic subjects are affected by type 2 diabetes (T2D). It is considered a chronic disease that affects life expectancy and leads to many issues such as heart problems, kidney failure, foot amputation, vision problems and the damages which affected the nervous system [1]. The mechanism of the two types of diabetes is different; in type I diabetes (T1D) there is an autoimmune re- action that leads to $\beta$-cells destruction, therefore, insulin synthesis is not sufficient. Type 2 diabetes mellitus is characterized not only by imbalance at redox states of pancreatic beta cells that is related to high glucose levels but above all by the development of insulin resistance and relative insulin deficiency [2].

The bioactive form of carnitine is known as Lcarnitine (3-hydroxy-4-N-trimethyl-aminobutyrate) which is synthesized in kidney and liver from essential amino acids, Lysine, and Methionine. L-car-

(C) 2020 Shahouzehi B. et al. This is an open-access article distributed under the terms of the Creative Commons Attribution License, which permits unrestricted use, distribution, and reproduction in any medium, provided the original author and source are credited. 
nitine facilitates fatty acids (with $>14$ carbon atoms) transports from the cytoplasm to mitochondria and promotes fatty acids beta-oxidation. According to this action of L-carnitine and its direct effect on lipid metabolism, it seems that L-carnitine can be involved in the metabolic disease process to attenuate these diseases effects [3,4]. Carnitine deficiency has been reported in diabetic patients and associated with liver and kidney diseases [3,5]. Argani and colleagues (2005) showed that HDL-c was increased and VLDL and TG levels were decreased in hemodialysis patients who received $500 \mathrm{mg} /$ day carnitine orally for 60 days [6]. There are studies of the beneficial effects of L-carnitine supplementation in chronic diseases such as diabetes and cardiovascular disease $[4,7,8]$. Also, it has been reported that carnitine supplementation improves insulin-stimulated glucose uptake [9].

AMPK (AMP-activated protein kinase) is an enzyme that plays a pivotal role in energy homeostasis. It also is known as cellular energy sensor which promotes catabolic pathways such as fatty acid $\beta$-oxidation, on the other hand; it inhibits synthetic pathways (Gluconeogenesis and Lipogenesis) to increase cell 'energy levels $[4,10]$. Adiponectin is a protein hormone and involved in lipid and glucose metabolism. There is some evidence that adiponectin has anti-atherogenic and insulin-sensitizing effects in human and animal models [11]. AMPK is a target of adiponectin which exerts its effects by modulating AMPK activity [4].

Pancreatic beta cells are very sensitive to oxidative agents from endogenous (superoxide anion and $\mathrm{H}_{2} \mathrm{O}_{2}$ during oxidative phosphorylation in mitochondria) or exogenous (Streptozotocin; STZ) sources [2]. Lipotoxicity associated with insulin resistance and beta-cell dysfunction and apoptosis in T2D. Therefore reduced lipid levels and obesity in diabetes can attenuate lipotoxicity deleterious effects in diabetic patients [12]. There is strong evidence from human and animal studies that have shown that lipid accumulation leads to insulin resistance and other metabolic complications. Also, it reported that carnitine supplementation improves insulin-stimulated glucose uptake [9]. Peroxisome proliferator-activated receptor gamma (PPAR $\gamma$ ) mainly expressed in adipose tissue and the lower level of expression was reported in skeletal muscle and liver. PPAR $\gamma$ induces fatty acid storage in adipose tissue. It seems that PPAR $\gamma$ directing fatty acid to adipose tissue rather than skeletal muscle and therefore attenuates insulin resistance in diabetes $[13,14]$. Previous studies have shown that PPAR $\gamma$ effects are exerted through adipogenesis and affecting glucose and lipid homeostasis, inflammation [14].

L-carnitine administration reduced serum lipid and glucose levels. Also, it showed promising antidiabetic and anti-obesity effects [4, 5, 7, 15-17]. But the data over L-carnitine hypoglycemic properties are not consistent $[7,17,18]$. Following our previous study which we evaluated L-carnitine effects in a T1D rat model; here we evaluated L-carnitine oral administration effects in rat models of T2D. Therefore, we measured AMPK, PPAR $\gamma$ and APPL1 (adaptor protein containing pleckstrin homology domain, phosphotyrosine binding (PTB) domain, and leucine zipper motif) genes expression in the liver and serum adiponectin and insulin level in diabetic rats. We designed this study to focus on the L-carnitine mechanism of action which alters lipid metabolism. Because its beneficial effects were previously reported in diabetic rats, therefore we evaluated L-carnitine effects on the expression of AMPK and PPAR $\gamma$ genes which are involved in lipid metabolism regulation.

\section{Materials and Methods}

Materials. Insulin (ELR Insulin) and Adiponectin (ELR Adiponectin) ELISA kits were purchased from Crystal Day Biotec. STZ (S0130), Nicotinamide (N3376) and L-carnitine (C0283) were supplied from Sigma. Nicotinamide was dissolved in saline and was introduced to animals by i.p. injection, STZ prepared in citrate buffer $(0.1 \mathrm{~N}, \mathrm{pH} 4.5)$ and introduced to animals by a single i.p injection and L-carnitine was prepared daily in phosphate buffer ( $\mathrm{pH}$ 7.4) and administrated orally to diabetic rats.

Methods. All the animal procedures were in accordance with the requirements of the European Convention for the protection of vertebrate animals used for experimental and other scientific purposes. This study was approved by the ethics committee of the Kerman Medical University Research Council (No. IR.KMU.REC960110, Nov 2018). We randomly selected 24 male Wistar rats $(200 \pm 10 \mathrm{~g}$ weight), after 7 days acclimatization the animals were randomly divided into three groups $(n=8)$ as follow; group 1 , healthy control which did not receive any treatment, group 2, diabetic control which received a single dose of STZ $(45 \mathrm{mg} / \mathrm{kg})$ and nicotinamide $(200 \mathrm{mg} / \mathrm{kg})$ by i.p injection to induce diabetes, group 3, diabetic rats plus L-carnitine which received a single dose of STZ $(45 \mathrm{mg} / \mathrm{kg})$ and nicotina- 
mide $(200 \mathrm{mg} / \mathrm{kg})$ by i.p injection and also $600 \mathrm{mg} /$ $\mathrm{kg} /$ day carnitine orally for 35 days. Diabetes was induced in rats (10 h fasted) by i.p injection of a single dose of STZ (45 mg/kg), followed by i.p injection of nicotinamide $(200 \mathrm{mg} / \mathrm{kg})$ after $15 \mathrm{~min}[4,19]$. First of all, we tested that the animals in groups 2 and 3 were diabetic before the L-carnitine treatment begins, for this reason, three days after the STZ and nicotinamide injections the blood sample was collected and glucose levels were measured and animals that their blood glucose levels were $>200 \mathrm{mg} / \mathrm{dl}$ after $10 \mathrm{~h}$ fasting were entered to this study. At the end of the study (day 35), after $10 \mathrm{~h}$ fasting overnight, animals were anesthetized by ether and decapitated, the liver tissues were dissected and washed with cold saline and immediately frozen by liquid nitrogen and kept in $-80^{\circ} \mathrm{C}$. Also, the blood sample was collected and maintained $1 \mathrm{~h}$ at room temperature and centrifuged and then serum was collected to measure the glucose, adiponectin, and insulin levels [4, 17].

Determination of serum adiponectin and insulin levels. Specific ELISA kits were used to assay adiponectin and insulin in serum. All measurements were according to the manufacturer's protocol.

Semi-quantitative Reverse Transcriptase PCR (RT-PCR). Total RNA was extracted from about $75 \mathrm{mg}$ of liver tissue by guanidine isothiocyanate phenol-chloroform method (RNX plus reagent). The tissues were homogenized by Hielscher Ultrasonic Processor (UP200H). The cDNA was synthesized by $\mathrm{M}-\mathrm{MuLV}$ reverse transcriptase and oligo-dT primers from 500 nanograms of extracted total RNA. The RT-PCR reactions were performed by Bio-Rad MJ Mini Personal thermal cycler. Each RT-PCR reaction contained 10 ul RT-PCR master mix, 200 nanograms of cDNA, primers ( $50 \mathrm{pM}$ of target genes' forward and reverse primers), and the final volume was $20 \mu \mathrm{l}$. The cycles for RT-PCR were as follow; $95^{\circ} \mathrm{C}$ for $10 \mathrm{~min}$, then 30 cycles of $95^{\circ} \mathrm{C}$ for $45 \mathrm{~s}$, $60^{\circ} \mathrm{C}$ for $1 \mathrm{~min}$, and $45 \mathrm{~s}$ at $72^{\circ} \mathrm{C}$, and $5 \mathrm{~min}$ final extension at $72^{\circ} \mathrm{C}$. After RT-PCR was done, we performed agarose gel electrophoresis to analyze the RT-PCR products ( $2 \%$ agarose gel, $100 \mathrm{v}$, and $45 \mathrm{~min}$ ). Primers are shown in Table 1 and were prepared from MACROGEN (MACROGEN Inc., Seoul, South Korea). Beta-actin was used as housekeeping gene. Finally, the bands on the gel were visualized and their densities were measured by using Image J software [4].

Statistical analysis. Statistical analysis performed by SPSS software (SPSS ver. 19, SPSS Inc., Chicago, USA) and the data expressed as mean \pm SEM. For comparison between groups, we used a one-way analysis of variance (ANOVA) followed by Tukey's post hoc test.

\section{Results and Discussion}

Our results showed that oral L-carnitine administration reduced fasting glucose compared to diabetic groups $(P=0.001, P=0.0001$ respectively). The insulin level in the diabetic group significantly reduced compared to the control group $(P=0.001)$ but there was no significant change between diabetic and L-carnitine treated groups. Adiponectin levels remarkably promoted by oral L-carnitine administration compared to diabetic non treated rats $(P=0.0001)$ (Table 2). Homeostasis model assessment-estimated insulin resistance (HOMA-IR) as a method to measure pancreas beta-cells function and insulin resistance in peripheral tissues significantly increased in the diabetic group and reduced in the group that received oral L-carnitine (Table 2).

Gene expression data showed that $A M P K$, $A P P L 1$, and PPAR $\gamma$ expression were reduced in the diabetic group $(P=0.002, P<0.0001$, and $P=0.001)$ and their expressions were promoted compared to diabetic group by oral L-carnitine administration $(P=0.029, P=0.039$ and $P=0.026)$ (Fig. 1-3).

Currently, L-carnitine is available as an oral supplement and it is used to reduce weight. It has been reported that $\mathrm{L}$-carnitine values affected in diabetes and L-carnitine supplementation showed

Ta ble 1. Sequences of the primers which used in this study for RT-PCR

\begin{tabular}{l|l|c|c}
\hline Transcript & \multicolumn{1}{|c|}{ Forward primer $\left(5^{\prime}-3^{\prime}\right)$} & \multicolumn{1}{c}{ Reverse primer $\left(5^{\prime}-3^{\prime}\right)$} & $\begin{array}{c}\text { Product } \\
\text { size (bp) }\end{array}$ \\
\hline AMPK & AGAGAACGTGTTGCTGGACG & TGGAGGCGAGGTAGAACTCA & 608 \\
APPL1 & TTTCTTAGGAAGGGGCTGCG & TGGCATCAGCGAGTTGAGTT & 450 \\
PPAR $\gamma$ & TGATGCACTGCCTATGAGCAC & TGAGACATCCCCACAGCAAG & 561 \\
$\beta$-Actin & TGAGAGGGAAATCGTGCGTG & TGCTTGCTGATCCACATCTGC & 682 \\
\hline
\end{tabular}


Table 2. Serum glucose, insulin and adiponectin levels and L-carnitine supplementation effects on these parameters in diabetic rats

\begin{tabular}{l|c|c|c|c}
\hline \multicolumn{1}{c|}{ Groups } & FBG, mg/dl & Insulin, mIU/1 & Adiponectin, $\mu \mathrm{g} / \mathrm{ml}$ & HOMA-IR \\
\hline Control & $93.2 \pm 4.5$ & $7.75 \pm 0.51$ & $10.32 \pm 0.78$ & $1.7 \pm 0.08$ \\
Diabetes & $292 \pm 6.8^{* *}$ & $5.08 \pm 0.49^{*}$ & $5.31 \pm 0.44^{* *}$ & $3.7 \pm 0.41^{*}$ \\
Diabetes + L-Carnitine & $120 \pm 7.6^{* \# \#}$ & $6.13 \pm 0.75$ & $10.31 \pm 0.8^{\# \#}$ & $2.0 \pm 0.39^{\#}$ \\
\hline
\end{tabular}

The data are expressed as mean \pm SEM. *Statistically significant compared to control group, \#statistically significant compared to diabetes control group, $(n=8)$. ${ }^{*} P<0.001,{ }^{* *} P<0.0001$, ${ }^{\#} P<0.0001$

beneficial effects in diabetes [15]. The mechanism of L-carnitine actions mainly is dependent on its role in fatty acids entrance into the mitochondria to be catabolized and produce energy. This effect reduces circulating lipid levels and attenuates insulin resistance. Therefore L-carnitine supplements help the insulin to exert its action in the body, effectively. There is no more evidence of the L-carnitine mechanism of action; hence, we evaluated oral Lcarnitine supplementation effects in T2D rat models

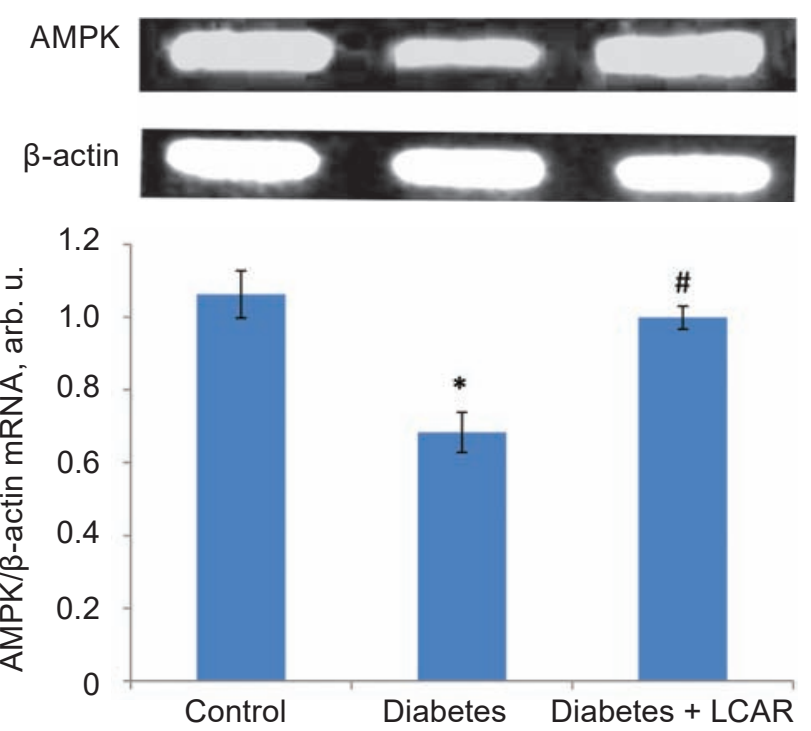

Fig. 1. AMPK gene expression in the liver, evaluation by reverse-transcriptase PCR at studied groups, the control group which did not receive any treatment, Diabetic control group which received single i.p injection of STZ $(45 \mathrm{mg} / \mathrm{kg})$ plus nicotinamide $(200 \mathrm{mg} / \mathrm{kg})$, and Diabetic + LCAR group which received STZ and nicotinamide as group 2 plus $600 \mathrm{mg} / \mathrm{kg} / \mathrm{d}$ L-carnitin orally for 5 weeks. Data are expressed as mean \pm SEM. * statistically significant compared to the control group, " statistically significant compared to the diabetic control group. $(P<0.05$ was considered as significant $)$ induced by a combination of STZ and nicotinamide administration.

The risk of carnitine deficiency is higher in patients with T2D. On the other hand, carnitine administration in obese rats developed insulin resistance ameliorated glucose tolerance and improved diabetes status $[5,15]$. Four weeks L-carnitine s.c administration $(50 \mathrm{mg} / \mathrm{kg})$ elevated glucose uptake and reduced blood glucose [16]. Another study has shown that six weeks L-carnitine $(600 \mathrm{mg} / \mathrm{kg} / \mathrm{day}$


Fig. 2. APPL1 gene expression in the liver, evaluation by reverse-transcriptase PCR at studied groups, the control group which did not receive any treatment, Diabetic control group which received single i.p injection of STZ $(45 \mathrm{mg} / \mathrm{kg})$ plus nicotinamide $(200 \mathrm{mg} / \mathrm{kg})$, and Diabetic + LCAR group which received STZ and nicotinamide as group 2 plus $600 \mathrm{mg} / \mathrm{kg} / \mathrm{d}$ L-carnitin orally for 5 weeks. Data are expressed as mean $\pm S E M$. * statistically significant compared to the control group, " statistically significant compared to the diabetic control group. $(P<0.05$ was considered as significant $)$ 

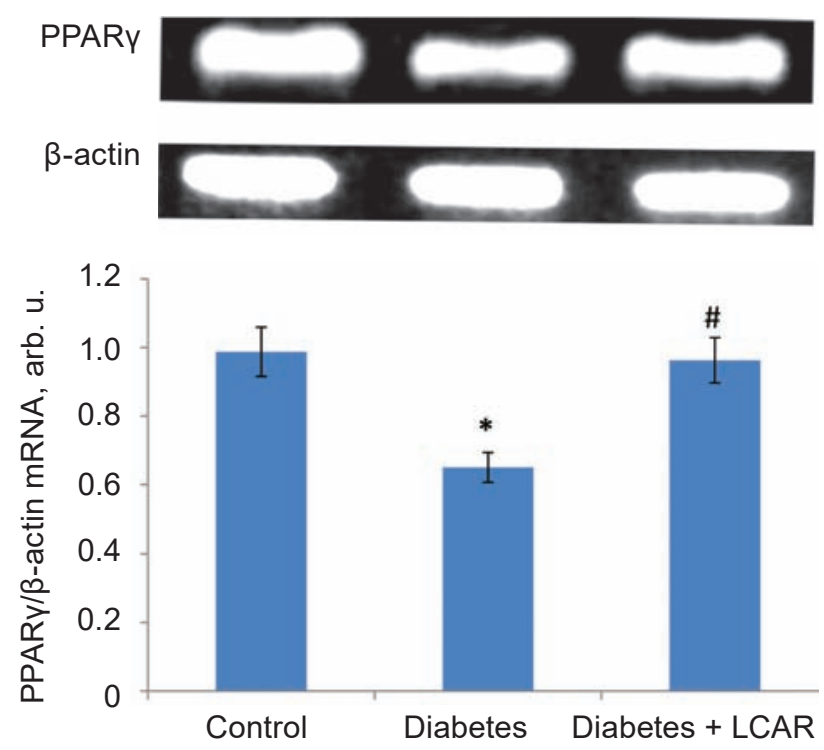

Fig. 3. PPARy gene expression in the liver, evaluation by reverse-transcriptase PCR at studied groups, the control group which did not receive any treatment, Diabetic control group which received single i.p injection of STZ (45 mg/kg) plus nicotinamide $(200 \mathrm{mg} / \mathrm{kg})$, and Diabetic + LCAR group which received STZ and nicotinamide as group 2 plus $600 \mathrm{mg} / \mathrm{kg} / \mathrm{d}$ L-carnitin orally for 5 weeks. Data are expressed as mean \pm SEM. *statistically significant compared to the control group, "statistically significant compared to the diabetic control group. $(P<0.05$ was considered as significant $)$

orally) administration in neonatal STZ $(90 \mathrm{mg} / \mathrm{kg}$ ) induced diabetic rats reduced serum lipid levels and showed beneficial effects over hyperglycemia and hyperinsulinemia. This carnitine supplementation in the diabetic model compensates the carnitine deficiency and therefore have ameliorated glucose and lipid metabolism [17]. Our study indicates that carnitine long term ( 5 weeks, $600 \mathrm{mg} / \mathrm{kg} /$ day orally) administration normalized diabetes-associated glucose levels in a T2D rat model.

One and four weeks L-carnitine different doses (200 or $400 \mathrm{mg} / \mathrm{kg} /$ day) administration in alloxaninduced diabetic rats showed that the blood glucose was not reduced, but TG and cholesterol levels were normalized. They assumed that reduced blood TG levels by carnitine administration are independent of hyperglycemia [7]. We showed that long term oral L-carnitine supplementation reduced blood glucose compared to the diabetic non-treated group and this finding is in contrast with some studies which found no effects of L-carnitine on glucose levels [7, 17].
Rodrigues et al. reported that a high dose of L-carnitine ( $3 \mathrm{~g} / \mathrm{kg} /$ day, i.p.) remarkably reduced glucose and lipid values, and this high dose of L-carnitine also affected the severity of diabetes in chronically diabetic rats [18].

PPAR $\gamma$ plays a pivotal function in some pathological and metabolic diseases such as atherosclerosis, diabetes mellitus, and inflammation. It has been reported that $P P A R \gamma$ promotes insulin sensitivity, and affects intracellular lipid contents $[13,14,20]$. $P P A R \gamma$ mainly expressed in adipose tissue and the lower level of expression was reported in skeletal muscle and liver. It directing fatty acid to adipose tissue rather than skeletal muscle and therefore attenuates insulin resistance in diabetes [13]. It has been reported that $P P A R \gamma$ knockout in the liver results in hyperlipidemia and insulin resistance [21].

Long term L-carnitine supplementation increased PPAR $\gamma$ expression and decreased oxidative stress in male rats. Also, they showed that 6 weeks L-carnitine treatment regulates GLUT 2 and Glut 4 expression and therefore affected and improved energy metabolism [22]. Our data showed that 5 weeks oral L-carnitine administration up-regulated PPAR $\gamma$, adiponectin and AMPK expression compared to the diabetic group. Hence, L-carnitine uses two possible different mechanisms to improve insulin resistance and attenuate hyperglycemia. $P P A R \gamma$ up-regulation directing fatty acids toward adipose tissue and also can increase fat storage at adipose tissue, therefore, it reduces circulating TG and alleviates insulin resistance [13]. It has been reported that PPAR $\gamma$ can increase adiponectin levels. By elevation of adiponectin and according to its insulinsensitizing effects it seems that L-carnitine by elevation of adiponectin improved insulin sensitivity in diabetic rats.

The enzyme AMPK considered as energy sensor which has an important role in the homeostasis of cellular energy [4]. Adiponectin is a hormone that regulates metabolism in the liver and exerts its effects by affecting AMPK activity. It also related to diseases such as diabetes, atherosclerosis and other metabolic complications. Previous studies have shown adiponectin anti-diabetic, anti-atherogenic and insulin-sensitizing effects $[4,14]$. The net effects of adiponectin decrease glucose production in the liver and insulin-sensitizing effects in liver and skeletal muscle [14]. We showed that L-carnitine supplementation increased liver $A M P K$ expression and serum adiponectin levels in diabetic rats com- 
pared to the diabetic control group. These findings support the beneficial effects of L-carnitine oral administration in diabetes. Poorabbas et al. (2007) have shown that L-carnitine supplementation in diabetic patients with diabetes complications is useful which are along with our findings over L-carnitine beneficial effects in diabetes [5]. Monsalve and colleagues (2013), reported that adiponectin levels reduced in diabetes, we found reduced values of serum adiponectin in diabetic rats which increased following L-carnitine oral administration [14].

Adiponectin downstream effects are conducted through the transmembrane receptor. Adiponectin binding to its specific receptor cause some modification and result in recruitment of APPL1 by intracellular domain of adiponectin receptor. It has been reported that in the liver, APPL1 has an important role in adiponectin signaling [23-25]. Our results showed that 5 weeks of oral L-carnitine supplementation upregulated APPL1 expression compared to diabetic control rats. Therefore, adiponectin binds to its receptor and recruits APPL1 and downstream cascade to include $A M P K$ activation and insulin-sensitizing effects that are under control of adiponectin. These findings indicating that adiponectin is responsible for some useful effects that we observed following L-carnitine administration to diabetic rats.

L-carnitine constant infusion improves insulin sensitivity in insulin-resistant diabetic patients; a significant effect on whole-body insulin-mediated glucose uptake is also observed in normal subjects. In diabetics, glucose, taken up by the tissues, appears to be promptly utilized as fuel since glucose oxidation is increased during L-carnitine administration. The significantly reduced plasma levels of lactate suggest that this effect might be exerted through the activation of pyruvate dehydrogenase, whose activity is depressed in the insulin-resistant status [26].
HOMA-IR is extensively used in epidemiological studies and clinical practice which is an important predictor for T2D. [27, 28]. We found that 5 weeks L-carnitine administration to diabetic rats' reduced HOMA-IR value and therefore the insulin sensitivity was increased following L-carnitine treatment. Pancreatic beta cells are very sensitive to oxidative agents from endogenous (superoxide anion and $\mathrm{H}_{2} \mathrm{O}_{2}$ during oxidative phosphorylation in mitochondria) or exogenous (STZ) sources [2]. Lipotoxicity associated with insulin resistance and beta-cell dysfunction in T2D. Therefore reduced lipid levels and obesity in diabetes can attenuate lipotoxicity deleterious effects in diabetes [12]. Due to the beneficial effects of L-carnitine, it seems that it's able to reduce circulating fatty acids levels and reduce lipotoxicity deleterious effects in diabetic rats.

Conclusions

The data from previous studies on L-carnitine effects on diabetes showed that long term L-carnitine therapy is more beneficial than the short term. Also, the most effective dose of L-carnitine needs to be determined because the studies have used different doses of L-carnitine and on the other hand the type of administration is different between studies. These parameters need to be reviewed more specifically and also there is a necessity of a dose-response study about L-carnitine effects on diabetes models $[4,7,15-18]$.

Conflict of interest. Authors have completed the Unified Conflicts of Interest form at http://ukrbiochemjournal.org/wp-content/uploads/2018/12/ coi_disclosure.pdf and declare no conflict of interest.

Acknowledgements. The present article was financially supported by the Kerman Medical University Research Council.

Funding. This study was funded by Kerman Medical University Research Council. 
ВПЛИВ L-КАРНІТИНУ НА ЕКСПРЕСІЮ ГЕНІВ АМРК, АPPL1 I PPAR $\boldsymbol{B}$ В ПЕЧІНЦІ ТА РIВЕНЬ

АДИПОНЕКТИНУ I HOMA-IR У СИРОВАТЦІ ЩУРІВ ІЗ ДІАБЕТОМ 2-ГО ТИПУ, ІНДУКОВАНИМ СТРЕПТОЗОТОЦИНОМ ТА НІКОТИНАМІДОМ

\section{B. Shahouzehi ${ }^{1,2}$, H. Fallah ${ }^{3}$, Y. Masoumi- Ardakani ${ }^{4 \bowtie}$}

${ }^{1}$ Student Research Committee, Kerman University of Medical Sciences, Kerman, Iran;

${ }^{2}$ Cardiovascular Research Center, Institute of

Basic and Clinical Physiology Sciences, Kerman

University of Medical Sciences, Kerman, Iran;

${ }^{3}$ Department of Biochemistry,

Afzalipour School of Medicine,

Kerman University of Medical Sciences, Kerman, Iran;

${ }^{4}$ Physiology Research Center, Institute of Basic and Clinical Physiology Sciences, Kerman

University of Medical Sciences, Kerman, Iran; 凶e-mail: ymab125@gmail.com

Цукровий діабет - хронічне захворювання найважливіша проблема охорони громадського здоров'я в усьому світі. L-карнітин в організмі синтезується в печінці та сприяє окисленню жирних кислот. Сьогодні його використовують як добавку за боротьби із зайвою вагою. Рівень карнітину знижується у хворих на цукровий діабет. Низкою досліджень показано позитивний ефект карнітину за діабету. Але механізм цього ефекту до кінця не вивчений. Отже, нами вивчено вплив перорального введення L-карнітину на експресію $A M P K$ та $P P A R \gamma$ у печінці і рівень адипонектину та інсуліну в сироватці крові діабетичних щурів. Випадковим чином щурів було розділено на три групи $(n=8)$ : група 1 - контрольна група, тварини не отримували жодних препаратів; група 2 - діабетичний контроль, тваринам вводили в/ч ін'єкцією стрептозотоцин (45 мг/кг) та нікотинамід (200 мг/кг); група 3 - діабетичні щури, які отримували карнітин 600 мг/кг/добу перорально протягом 35 днів. Застосування L-карнітину дозволило знизити рівень глюкози натще порівняно $з$ контрольною і діабетичною групами $(P=0,001, P=0,0001$ відповідно). Рівень інсуліну в діабетичній групі значно знизився порівняно $з$ контрольною групою. За застосування L-карнітину спостерігали підвищення рівня адипонектину в порівнянні зі щурами групи діа- бетичного контролю $(P=0,0001)$. Індекс інсулінорезистентності (HOMA-IR) істотно збільшився в діабетичній групі та зменшився в групі, яка отримувала перорально L-карнітин. L-карнітин виявляв сприятливий ефект на щурів із діабетом 2-го типу завдяки підвищенню регуляції експреciї AMPK, PPAR $\gamma$ та APPL1 генів, а також підвищенню рівня адипонектину в сироватці крові, що має інсулінсенсибілізаційний ефект.

К л ю ч о в і с л о в а: L-карнітин, діабет, нікотинамід, HOMA-IR, AMPK, PPAR $\gamma$, APPL1.

\section{References}

1. Guariguata L, Whiting DR, Hambleton I, Beagley J, Linnenkamp U, Shaw JE. Global estimates of diabetes prevalence for 2013 and projections for 2035. Diabetes Res Clin Pract. 2014; 103(2): 137-149.

2. Wang J, Wang H. Oxidative Stress in Pancreatic Beta Cell Regeneration. Oxid Med Cell Longev. 2017; 2017: 1930261.

3. Flanagan JL, Simmons PA, Vehige J, Willcox MD, Garrett Q. Role of carnitine in disease. Nutr Metab (Lond). 201; 7: 30.

4. Shahouzehi B, Barkhordari K, Aminizadeh S, Masoumi-Ardakani Y. Effect of L-carnitine administration on serum insulin and adiponectin levels, and AMPK, APPL1 and PPAR $\gamma$ gene expression in STZ-induced diabetic rat liver. Ukr Biochem J. 2017; 89(6): 48-55.

5. Poorabbas A, Fallah F, Bagdadchi J, Mahdavi R, Aliasgarzadeh A, Asadi Y, Koushavar H, Vahed Jabbari M. Determination of free L-carnitine levels in type II diabetic women with and without complications. Eur J Clin Nutr. 2007; 61(7): 892-895.

6. Argani H, Rahbaninoubar M, Ghorbanihagjo A, Golmohammadi Z, Rashtchizadeh N. Effect of L-carnitine on the serum lipoproteins and HDL-C subclasses in hemodialysis patients. Nephron Clin Pract. 2005; 101(4): c174-c179.

7. Bazotte RB, Lopes-Bertolini G. Effects of oral L-carnitine and DL-carnitine supplementation on alloxan-diabetic rats. Braz Arch Biol Technol. 2012; 55(1): 81-88.

8. D'Antona G, Nabavi SM, Micheletti P, Di Lorenzo A, Aquilani R, Nisoli E, Rondanelli M, Daglia M. Creatine, L-carnitine, and $\omega 3$ polyunsaturated fatty acid supplementation from healthy to diseased skeletal muscle. Biomed Res Int. 2014; 2014: 613890. 
9. Mynatt RL. Carnitine and type 2 diabetes. Diabetes Metab Res Rev. 2009; 25(Suppl 1): S45-S49.

10. Mihaylova MM, Shaw RJ. The AMPK signalling pathway coordinates cell growth, autophagy and metabolism. Nat Cell Biol. 2011;13(9):1016-1023.

11. Achari AE, Jain SK. Adiponectin, a therapeutic target for obesity, diabetes, and endothelial dysfunction. Int J Mol Sci. 2017; 18(6): 1321.

12. DeFronzo RA. Insulin resistance, lipotoxicity, type 2 diabetes and atherosclerosis: the missing links. The Claude Bernard Lecture 2009. Diabetologia. 2010; 53(7): 1270-1287.

13. Ferré P. The biology of peroxisome proliferatoractivated receptors: relationship with lipid metabolism and insulin sensitivity. Diabetes. 2004; 53 Suppl 1: S43-S50.

14. Monsalve FA, Pyarasani RD, Delgado-Lopez F, Moore-Carrasco R. Peroxisome proliferatoractivated receptor targets for the treatment of metabolic diseases. Mediators Inflamm. 2013; 2013: 549627.

15. Cave MC, Hurt RT, Frazier TH, Matheson PJ, Garrison RN, McClain CJ, McClave SA. Obesity, inflammation, and the potential application of pharmaconutrition. Nutr Clin Pract. 2008; 23(1): 16-34.

16. Abdel-Razek HAD. Beneficial effect of $\mathrm{L}$-carnitine on the neuromuscular performance in diabetic rats. Menoufia Med J. 2010; 23: 159173.

17. Patel J, Goyal R, Bhatt P. Beneficial effects of levo-carnitine on lipid metabolism and cardiac function in neonatal streptozotocin rat model of diabetes. Int J Diabetes Metab. 2008; 16: 29-34.

18. Rodrigues B, Xiang H, McNeill JH. Effect of L-carnitine treatment on lipid metabolism and cardiac performance in chronically diabetic rats. Diabetes. 1988; 37(10): 1358-1364.

19. Szkudelski T. Streptozotocin-nicotinamideinduced diabetes in the rat. Characteristics of the experimental model. Exp Biol Med (Maywood). 2012; 237(5): 481-490.

20. Sharma S, Sun X, Rafikov R, Kumar S, Hou Y, Oishi PE, Datar SA, Raff G, Fineman JR, Black SM. PPAR- $\gamma$ regulates carnitine homeostasis and mitochondrial function in a lamb model of increased pulmonary blood flow. PLoS One. 2012; 7(9): e41555.
21. Gavrilova O, Haluzik M, Matsusue K, Cutson JJ, Johnson L, Dietz KR, Nicol CJ, Vinson C, Gonzalez FJ, Reitman ML. Liver peroxisome proliferator-activated receptor gamma contributes to hepatic steatosis, triglyceride clearance, and regulation of body fat mass. $J$ Biol Chem. 2003; 278(36): 34268-34276.

22. Pala R, Genc E, Tuzcu M, Orhan C, Sahin N, Er B, Cinar V, Sahin K. L-Carnitine supplementation increases expression of PPAR- $\gamma$ and glucose transporters in skeletal muscle of chronically and acutely exercised rats. Cell Mol Biol. 2018; 64(1): 1-6.

23. Deepa SS, Zhou L, Ryu J, Wang C, Mao X, Li C, Zhang N, Musi N, DeFronzo RA, Liu F, Dong LQ. APPL1 mediates adiponectin-induced LKB1 cytosolic localization through the PP2APKCzeta signaling pathway. Mol Endocrinol. 2011; 25(10): 1773-1785.

24. Deepa SS, Dong LQ. APPL1: role in adiponectin signaling and beyond. Am J Physiol Endocrinol Metab. 2009; 296(1): E22-E36.

25. Mao X, Kikani CK, Riojas RA, Langlais $P$, Wang L, Ramos FJ, Fang Q, Christ-Roberts CY, Hong JY, Kim RY, Liu F, Dong LQ. APPL1 binds to adiponectin receptors and mediates adiponectin signalling and function. Nat Cell Biol. 2006; 8(5): 516-523.

26. Mingrone G, Greco AV, Capristo E, Benedetti G, Giancaterini A, De Gaetano A, Gasbarrini G. L-carnitine improves glucose disposal in type 2 diabetic patients. J Am Coll Nutr. 1999; 18(1): 77-82.

27. Bonora E, Formentini G, Calcaterra F, Lombardi S, Marini F, Zenari L, Saggiani F, Maurizio Poli M, Perbellini S, Raffaelli A, Cacciatori V, Santi L, Targher G, Bonadonna R, Muggeo M. HOMA-estimated insulin resistance is an independent predictor of cardiovascular disease in type 2 diabetic subjects: prospective data from the Verona Diabetes Complications Study. Diabetes Care. 2002; 25(7): 1135-1141.

28. Salgado ALFA, Carvalho L, Oliveira AC, Santos VN, Vieira JG, Parise ER. Insulin resistance index (HOMA-IR) in the differentiation of patients with non-alcoholic fatty liver disease and healthy individuals. Arq Gastroenterol. 2010; 47(2): 165-169. 